\title{
NOVAS GEOPOLÍTICAS, IGREJAS E POPULAÇÃO SEM RELIGIÃO: ANARQUIA RELIGIOSA NO BRASIL?
}

\author{
Alberto Pereira dos Santos*
}

Resumo: Este artigo representa uma síntese de nossa tese de doutorado em geografia humana, defendida na Universidade de São Paulo. Quais as relações entre geopolítica e religião? Nossa hipótese considerou que as igrejas exercem geopolíticas para manter e expandir o "capital religioso". Por outro lado, a análise geográfica da realidade brasileira identifica um processo lento e fecundo de metamorfose das religiosidades e emancipação espiritual através do crescimento da população religiosa sem religião. Esse processo ocorre sem governo das igrejas. Fundamentado nas ideias de geoética e apoio mútuo, defende-se que a existência da população sem religião se configura como anarquia religiosa no Brasil.

Palavras-chave: geopolítica das igrejas, população sem religião, anarquia religiosa, apoio mútuo, geoética.

\section{NEW GEOPOLITICS, CHURCHES AND PEOPLE WITHOUT RELIGION: RELIGIOUS ANARCHY IN BRASIL?}

\begin{abstract}
This article represents a synthesis of our doctoral thesis in human geography, defended at the University of São Paulo. What are the relationships between geopolitics and religion? Our hypothesis held that churches make use of geopolitics to maintain and expand the "religious capital". On the other hand, the geographical analysis of the Brazilian reality identifies a slow and fruitful process of metamorphosis of beliefs and spiritual emancipation through the growth of the religious population without religion. This process occurs without the government of the churches. Based on the ideas of geoethic and mutual support, it is argued that the existence of the population without religion represents religious anarchy in Brazil.
\end{abstract}

Key Words: geopolitics of churches, people without religion, religious anarchy, mutual support, geoethic.

\section{Introdução}

As ideias desenvolvidas no presente artigo representam um esforço reflexivo em busca de uma síntese de nossa tese de doutorado em geografia humana, defendida na Universidade São Paulo. Tentarei expor as ideias principais da tese, embora sabendo das limitações deste artigo. Agradeço, neste espaço, a valiosa contribuição dos Avaliadores (ocultos) que emitiram seus pareceres com inúmeros comentários críticos, a partir dos quais busquei aperfeiçoar esta síntese. Isso, porém, não isentam - de maneira alguma - novas críticas sobre o texto aqui apresentado

O Brasil é um país religioso. Isso não se pode negar. Mas como explicar a aparente contradição entre, de um lado, a expansão do poder religioso no território (crescimento das igrejas evangélicas, disputas de poderes e influências através dos meios de comunicação principalmente entre a Igreja Católica e diversos segmentos protestantes) e, de outro lado, o crescimento da população sem religião no Brasil?

\footnotetext{
* Doutor e Mestre em Geografia Humana pela Universidade de São Paulo (USP). Professor Adjunto da Universidade do Estado do Rio de Janeiro (UERJ). E-mail: albert.geo@uol.com.br
} 
Separar radicalmente religião e política se constitui em tarefa quase impossível. Não é nossa pretensão. Ao contrário, ambas caminham juntas. Aliás, Nicolau Maquiavel (1469-1527), pensador italiano, clássico da Ciência Política, na obra O Príncipe, sugere que o governante ou político profissional para conquistar e se manter no poder - mesmo não possuindo as cinco qualidades - deve passar a impressão de homem misericordioso, sincero, íntegro, humanitário e religioso. Em suas palavras, "nada, aliás, se faz mais indispensável do que passar a impressão de possuir esta última qualidade." (MAQUIAVEL, 1998, p.102).

Como dar conta desse tema tão complexo, aqui intitulado, "Novas Geopolíticas, Igrejas e População sem religião: Anarquia Religiosa no Brasil?". Em primeiro lugar, alerta-se que não se pretende aqui esgotar essa discussão ou análise. Começaremos, porém, indicando as bases que tentam fundamentar o titulo deste artigo.

Estamos utilizando o conceito "novas geopolíticas", segundo a visão de Vesentini (2000). Nesta abordagem não estamos utilizando a palavra geopolítica em seu significado clássico quando esteve vinculado unicamente ao Estado, mas sim segundo um enfoque atual que leva em conta outros atores sociais no século XXI, tal como propõe o geógrafo José William Vesentini na obra Novas Geopolíticas. Nas palavras de VESENTINI (2000, p. 11)

As novas geopolíticas, em especial após o final da guerra fria e da ameaça de um holocausto nuclear, relativizam (mas não omitem) a questão da guerra militar e enfatizam outras "guerras" ou conflitos: econômicos, sociais, culturais e até simbólicos (na mídia e na indústria cultural, por exemplo). Embora o nome "geopolítica" continue a ser utilizado, o enfoque atualmente é outro. As novas geopolíticas, não por coincidência surgidas na "era da globalização" e enfraquecimento (relativo) dos Estados nacionais, normalmente não são feitas "para o Estado" e tampouco o veem como o único ator na política mundial. Novos atores ou sujeitos são levados em consideração, desde as civilizações ou grandes culturas até as ONG's. (grifo nosso)

Sobre o estudo aprofundado acerca da população, a abordagem de Amélia DAMIANI (1991), contribui sobremaneira para nossa análise. Segundo a geógrafa "a população constitui a base e o sujeito de toda a atividade humana" (DAMIANI, 1991, p.8). Mas para uma análise crítica da população, alerta-nos a autora, é necessário "destruir o objeto real, em sua complexidade; portanto, não iniciá-la pela população" (DAMIANI, 1991, p.9). E nesse sentido analítico, é possível criar categorias mais próximas da complexidade do real.

Nas palavras de Amélia Damiani:

"Esses elementos, ou categorias de análise que dão acesso à compreensão enriquecida da população, variam na medida em que são históricos e recuperam no nível do mundo pensado, a realidade sensível em movimento. $\mathrm{O}$ movimento da atividade humana e seus resultados históricos redefinem sempre as categorias mediadoras desse processo de conhecimento. Novas categorias de análise são gestadas." (DAMIANI, 1991, p.9).

Portanto, ao tratar nesta análise da "população sem religião", para fundamentar o conceito de "anarquia religiosa", como veremos mais adiante, nos distanciamos das formas de qualificá-la utilizadas pela demografia (DAMIANI, 1991, p.78).

Neste estudo privilegiamos a análise da população e sua relação com o poder religioso institucionalizado, nos inspirando na proposta do geógrafo francês Claude Raffestin que, ao fazer um balanço crítico da geografia política clássica, coloca a população como categoria principal para um estudo 
renovado de geografia política. (RAFFESTIN, 1993). E por que privilegiar a população neste estudo? Nas palavras de Raffestin:

Porque é a fonte do poder, o próprio fundamento do poder, por sua capacidade de inovação ligada ao seu potencial de trabalho. Assim, é por ela que passam todas as relações. (...) É por intermédio dela que todo o restante adquire um sentido e se carrega de significações múltiplas; é por causa dela que as coisas são coerentes, contraditórias ou paradoxais. (RAFFESTIN, 1993, p.7).

O que vem a ser população sem religião? Como terceiro maior segmento no quesito religião - os católicos e evangélicos são, respectivamente, o primeiro e o segundo - a população sem religião representa mais de 7\% da população brasileira (IBGE, 2000). Esse segmento - são mais de 12 milhões se constitui de pessoas não religiosas e pessoas religiosas sem religião. Ou seja, por uma minoria que se declara como ateu e/ou agnóstico (1\%) e a maior parte (6\%) de pessoas religiosas que se desvincularam das igrejas ou do poder religioso institucionalizado.

A respeito da minoria que se declara como ateus e agnósticos, vale ressaltar que essas pessoas também revelam valores e atitudes carregadas de certa espiritualidade, como sugere Mircea Eliade. Segundo esse pensador, "de certo ponto de vista, quase se poderia dizer que, entre os modernos que se proclamam a-religiosos, a religião e a mitologia estão 'ocultas' nas trevas de seu inconsciente" (ELIADE, 2001, p. 173) ${ }^{\mathrm{ii}}$.

Essa visão de que ateus e agnósticos expressam certa espiritualidade, também foi considerada numa pesquisa realizada na Pontifícia Universidade Católica de São Paulo (PUC-SP), como constatou o cientista da religião Jorge Ribeiro (RIBEIRO, 2009).

Nesse sentido, considera-se que nesta abordagem acerca da população sem religião, não se faz distinção radical entre esses dois grupos: ateus/agnósticos e religiosos sem igreja. Ao contrário, esses grupos compõem o mesmo segmento de população sem religião.

Entre a população sem religião se encontram pessoas ex-católicas (38\%), exevangélicas (28\%) e religiosas de "outras" denominações $(28,6 \%)$, segundo pesquisa dos sociólogos (professores da USP) Flavio Pierucci e Reginaldo Prandi (PIERRUCI \& PRANDI, 1996). Contata-se uma tendência de crescimento da população sem religião no Brasil, como indicam os dados do IBGE: 0,55\% (1960); 0,79\% (1970); 1,89\% (1980); 5\% (1991) e 7,3\% (2000).

Ressalta-se, porém, que, além da população sem religião aqui indicada, existem inúmeras pessoas católicas que se identificam como "não praticantes". Por sua vez, embora de modo menos generalizado, há também protestantes ou evangélicos que se podem considerar como "não praticantes", conforme revela um estudo organizado pelo pastor Rubens Muzio - do Serviço de Evangelização para a América Latina (SEPAL) -, realizado por uma equipe de pesquisadores protestantes (geógrafos, historiadores, sociólogos, assistentes sociais) da Universidade Estadual de Londrina (UEL). Por exemplo, em Londrina (no estado do Paraná), somente um terço dos evangélicos frequentam regulamente os cultos de domingo. Nas palavras do organizador do estudo, Rubens Muzio: "A crítica lançada por décadas à Igreja Católica Romana no Brasil agora também pode ser aplicada à igreja evangélica: a existência do nominalismo, de um Cristianismo cultural." (MUZIO, 2004, p.23).

Cabe ainda, nesta introdução, apresentar sucintamente os fundamentos da terceira ideia conceitual que compõe o subtítulo deste artigo, a saber, anarquia religiosa. A esse respeito nos apoiaremos nas 
contribuições dos geógrafos anarquistas Kropotkin (2001) e Reclus (2002), bem como na visão de Costa (1985) que nos auxiliam no entendimento do termo "anarquia", o qual significa etimologicamente "sem governo" ou ausência de governo.

Em nosso entendimento, exposto aqui de modo simplificado, anarquia religiosa significa "sem governo religioso", isto é, ausência de governo das igrejas sobre a população sem religião. Se essa população sem religião advém das igrejas - como os dados do IBGE e de outras fontes indicam -, e esse processo se configura como tendência cultural, entende-se que a anarquia religiosa pode vir a ser um processo lento e fecundo de emancipação espiritual, de autogoverno do patrimônio espiritual, de autonomia da fé da população sem religião no Brasil. Esse processo, a meu ver, contribui para o aperfeiçoamento e fortalecimento da cidadania no Estado Democrático de Direito, inserido na nova ordem planetária em gestação, isto é, no cenário de relações internacionais de governança sem governo (ROSENAU, 2000) ${ }^{\mathrm{iii}}$.

Sabe-se das limitações deste artigo, contudo, indicar-se-á como conclusão - ainda que aberta às críticas e ao novo - que a hipótese de geopolítica das igrejas se evidencia na realidade brasileira e, de outro lado, constata-se uma tendência de crescimento da população sem religião cujas preocupações na esfera da cidadania apontam para a busca de soluções socioambientais, para a "salvação", ou melhor, para a conservação da vida com ética na Terra. Daí a instituição imaginária (CASTORIADIS, 1993) de anarquia religiosa "por uma geoética de apoio mútuo ’iv.

\section{Bases epistemológicas da tese}

Todos nós sabemos o quanto é fundamental estabelecer as bases teóricas e metodológicas no processo de produção científica em qualquer área do conhecimento. $\mathrm{Na}$ Geografia essa preocupação não é diferente, isto é, qualquer que seja o tema de pesquisa a fundamentação teórica e metodológica se constitui em algo que legitima a produção científicav .

Nesse sentido, em se tratado do título deste artigo "Novas Geopolíticas, Igrejas e População sem religião: anarquia religiosa no Brasil?", talvez ao leitor pareça óbvia nossa opção teórica que pretende ser um estudo do território e do poder expansionista religioso no Brasil e do processo de desenvolvimento da autonomia da fé da população religiosa.

Este estudo se vincula à Geografia Humana, porém, sob uma ótica da geografia política, fundamentado no pensamento de diversos geógrafos como Élisée RECLUS (2002), Piotr KROPOTKIN (2001, 2009), Yves LACOSTE (1989, 2005), Claude RAFFESTIN (1993), J.William VESENTINI (2000, 2009), DAMIANI (1991), mas sempre aberto ao diálogo com clássicos como Max WEBER (1984, 2004), Karl MARX (1969), e outros cientistas sociais especialistas em estudos das religiões.

Pouquíssimos geógrafos brasileiros pesquisaram (e pesquisam) o tema da religião. O trabalho pioneiro foi a tese de doutorado de Maria Cecília França (19272010) intitulado "Pequenos centros paulistas de função religiosa", defendida em 1972 na Universidade de São Paulo. Numa perspectiva marxista, a dissertação de mestrado de Gualberto Gouveia, "A Cidadania dos despossuídos - Pentecostalismo e Segregação" defendida na USP em 1993. Outra pesquisa em geografia que tratou sobre religião é a tese "Porto das Caixas espaço sagrado na Baixada Fluminense", de Zeny Rosendahl, defendida na USP em 1994. Numa perspectiva que se aproxima de certa fenomenologia, vale lembrar o trabalho de 
mestrado intitulado "Geografia do (In)visível - o espaço do kardecismo em São Paulo", de Alberto Santos, defendido na USP em 1999. Além desses, existem poucos trabalhos de geógrafos sobre o tema religião.

Contudo, a escassa produção acadêmica em Geografia acerca do tema religião não inibiu a ousadia (ou pretensão) de dois geógrafos que defendem certa autonomia do que os autores chamam de "Geografia da Religião" (ROSENDAHL, 1996) e "Geografia do Sagrado" (GIL FILHO, 2001).

A respeito da Geografia da Religião, não se pode negar a produção da geógrafa Zeny Rosendahl que se constitui como legítima contribuição e referência teórica no pensamento geográfico brasileiro. Por sua vez, embora em menor proporção, a contribuição da Geografia do Sagrado na produção de Sylvio Gil Filho. Há, porém, críticas em relação a essas duas produções (ou subcampos) que se pretendem como autônomas dentro da Geografia. Nesse sentido, numa reflexão ponderada acerca da pretensa autonomização da "geografia da religião" e da "geografia do sagrado" para estudar o tema da religião no espaço geográfico, destacamos as palavras de GOMES (2009, p.73):

Isso não parece ser a atitude metodológica mais apropriada pois retira os objetos de estudos dos seus contextos, recolocando-os sob um foco único, que parece parasitar todos os outros elementos que porventura possam existir. Os fenômenos não são nunca exclusivamente econômicos, políticos ou culturais, mesmo porque teríamos dificuldade em defender os limites dessas esferas. Esses fenômenos são complexos e seu estudo deve dar margens a que possam ser avaliados sem seguir uma grade de concepções aprioristicamente definida.

O fato é que tanto a "geografia da religião" (ROSENDAHL, 1996), como a "geografia do sagrado" (GIL FILHO, 2001), não discutem os aspectos políticos intrínsecos à religião. $\mathrm{Na}$ atualidade o poder religioso, especialmente das igrejas evangélicas (mas não exclusivamente), se evidencia até mesmo no Congresso Nacional, inclusive com o envolvimento de parlamentares evangélicos em esquemas de corrupção, como explicita o cientista da religião Saulo Baptista (BAPTISTA, 2009).

Ao fazermos aqui uma opção epistemológica que entendemos como geografia crítica pluralista - isto é, uma geografia que tenta dialogar com vários geógrafos críticos (LACOSTE, 1989; DAMIANI, 1991; VESENTINI, 2009; RAFFESTIN，1993; SOJA，1993; CARLOS, 2011) e outros pensadores do social (MARX, 1969; FOUCAULT, 1979; FREUD, 1997; CASTORIADIS, 1993; MORIN, 2005, 2007) para analisar a dimensão política das igrejas e da população sem religião no território brasileiro, não se nega ou rejeita a dimensão simbólica, imaterial ou ontológica das crenças religiosas.

Essa opção epistemológica nos permite fazer um recorte teóricometodológico que privilegia a categoria população - segundo a visão de Amélia Damiani (DAMIANI, 1991) -, especialmente a relação população-religião e poder, como propõe Claude Raffestin (RAFFESTIN,1993).

Ainda no campo epistemológico, ao optar por estudar o fenômeno religioso no espaço social sob uma perspectiva da geografia humana com ênfase no aspecto político, acredita-se seja oportuno expressar nosso espírito de tolerância em relação às mais diversas formas ou sentidos de crença. Mas o respeito e a tolerância na convivência com pessoas que professam diferentes crenças religiosas não isenta, de maneira alguma, na análise científica, a visão crítica em relação ao aspecto político intrínseco ao espaço social das igrejas e das populações religiosas. 
Muito antes das primeiras pesquisas geográficas acerca do fenômeno religioso no Brasil, no século XIX o geógrafo anarquista francês Élisée Reclus (1830-1905) já havia feito reflexões críticas a respeito das manipulações católicas e protestantes, na Europa, que pretendiam a manutenção do estado de miséria e opressão do povo. Vejamos as palavras de RECLUS (2002, p.35):

\begin{abstract}
Sabe-se agora que a Reforma também foi uma constituição de outras igrejas autoritárias, diante da Igreja que até aquele momento tinha possuído o monopólio da escravidão intelectual. A Reforma deslocou as fortunas e as prebendas em proveito do novo poder, e de uma e de outra parte nasceram ordens, jesuítas e contra-jesuítas, para explorar o povo sob novas formas. Lutero e Calvino falaram em relação àqueles que não compartilhavam sua maneira de ver, a mesma linguagem de intolerância feroz que os São Domingo e os Inocêncio III. Assim como a inquisição, mandaram espionar, aprisionar, esquartejar, queimar; sua doutrina assentou igualmente como princípio a obediência aos reis e aos intérpretes da "palavra divina".
\end{abstract}

Embora tenha feito críticas às igrejas de sua época, Reclus foi criado numa família religiosa que o educou para seguir carreira eclesiástica. No entanto, ele desistiu de ser pastor. Em suas palavras:

"Havia durante muito tempo forjado em meu espírito o desejo de ser pastor; todavia, (...) resisti a todos os meus pequenos desejos de amor próprio, e por isso digo agora, não quero, não posso, não devo ser pastor. (...) tempos virão em que cada homem será seu próprio rei e seu próprio pastor, ...entre os homens não haverá nada além de influências recíprocas, vínculos de amor; cada um falará ao seu irmão das ideias que agitam sua mente, dos sentimentos que cruzam seu coração... não haverá quem governe ou conduza seus semelhantes... mas como alcançar esse futuro se não o realizamos em nós mesmos? (...) O nosso fim é chegar àquele estado de perfeição ideal no qual as nações não terão mais necessidade de estar sob a tutela de um governo ou de outra nação; e a ausência de governo é a ANARQUIA, A MAIS ELEVADA EXPRESSÃO DA ORDEM." (RECLUS, 2002. P.11)

Por sua vez, as ideias do geógrafo anarquista russo Piotr Kropotkin (1842-1920) também contribuem para a fundamentação teórica de nossa tese. Kropotkin é um dos mais citados personagens da história do anarquismo, responsável por ter colocado o ideal anarquista no campo do pacifismo, do humanismo, e radicalmente oposto à violência (VESENTINI, 2009) ${ }^{\text {vii. }}$.

Nesse sentido, busquemos resgatar aqui, embora numa longa citação, o significado da palavra anarquia segundo Kropotkin:

"De inicio, insistiram no hífen entre an e arquia, explicando que, sob esta forma, a palavra an-anarquia, de origem grega, significava ausência de poder, e não "desordem" (...) Contudo, esta palavra, dizem-nos, desperta no espírito a negação da ordem, portanto, a ideia de desordem, de caos. (...) A ordem, hoje - o que eles entendem por ordem - é a miséria, a fome, tornadas estado normal da sociedade. (...) A ordem é a mulher que se vende para alimentar seus filhos (...) A ordem é a guerra contínua de homem a homem, de profissão a profissão, de classe a classe, de nação a nação. Eis a ordem! $E$ a desordem - o que eles chamam de desordem? (...) A desordem é a eclosão das mais belas paixões e das maiores dedicações, é a epopeia do supremo amor pela Humanidade." (KROPOTKIN, 2001, p. 88-93) viii.

Ao invés da competição entre as pessoas, classes sociais e nações, Kropotkin propôs seu ideal de "apoio mútuo", isto é, a cooperação recíproca na busca de solução para os problemas sociais e humanos (KROPOTKIN, 2009) $)^{i x}$. 
Geopolíticas das Igrejas no Brasil - uma introdução

O que tem a ver geopolítica com religião? Veremos, sucintamente, que toda igreja que pretende manter e/ou expandir sua religião no espaço geográfico (local, nacional e/ou mundial), em alguma medida, exerce a geopolítica.

A geografia política clássica surgiu a partir das ideias do geógrafo alemão Friederich Ratzel (1897), mas a palavra geopolítica foi criada pelo jurista sueco Rudolf Keller em 1905. Décadas depois o general alemão Karl Haushofer popularizou a geopolítica a partir de uma Revista, algo que contribuiu para que Adolf Hitler utilizasse o saber geográfico para fazer a Grande Guerra (1939-1945). Por ter sido associada àquela guerra, a geopolítica praticamente foi banida do debate público e das pesquisas acadêmicas.

Contudo, o que se entende por geopolíticas das igrejas? Além da visão de Vesentini (2000) já apontada na introdução, indicaremos as ideias de Raffestin (1993) e Lacoste $(1989,2005)$ que contribuem para esta análise, isto é, para nossa visão acerca do que vem a ser geopolítica das igrejas.

Segundo Raffestin (1993), a geografia política clássica, desde Ratzel até a década de 1980 - com raras exceções como, por exemplo, a obra Geopolítica da Fome (1948), de Josué de Castro - esteve voltada para a análise do poder do Estado. Buscando renovar a geografia política, Raffestin propõe a abordagem focada no poder da população, na concepção foucaultiana (FOUCAULT, 1979).

Por sua vez, na obra "Novas Geopolíticas", Vesentini (2000) defende que a geopolítica, enquanto campo interdisciplinar, embora não omita o papel do Estado, enfatiza outras "guerras" ou conflitos: econômicos, sociais, culturais e até simbólicos (na mídia e na indústria cultural, por exemplo).

$\mathrm{Na}$ obra $A$ Geopolítica do Inglês o geógrafo francês Yves Lacoste sintetiza o conceito de geopolítica com as seguintes palavras: "por geopolítica, todos sabemos, entende-se toda rivalidade de poderes (e de influências) sobre territórios" (LACOSTE, 2005, p.7).

De modo geral, sabemos que as igrejas, enquanto estrutura de poder, possuem seus dogmas $e$ interesses em manter e/ou expandir seu "capital religioso", uma vez que, segundo o geógrafo francês Claude RAFFESTIN (1993, p.121):

A religião pode também ser
relacionada a um capital
constante. Capital sobre o
qual se exerce todo "trabalho
religioso" posterior. Mas,
como a língua, esse capital
constante é uma massa morta
se a ele não se acrescentar
um capital variável
constituído pelos fiéis que
formam a comunidade adepta
de uma religião.

Nessa perspectiva, as igrejas especialmente a católica e as evangélicas, mas não exclusivamente - desejam se expandir no espaço geográfico. Nesse sentido, de modo geral, as igrejas planejam suas estratégias objetivando a manutenção e a expansão de seu capital religioso, com a conquista de novos fiéis (população), mais dízimos e ofertas, meios de comunicação e territórios no espaço geográfico brasileiro e até mundial. A IURD, por exemplo, têm filiais em mais de 150 países no mundo. Mas uma questão se coloca: "os fins justificam os meios", ou qual seria o limite jurídico e ético das geopolíticas das igrejas?

No cenário político muitas igrejas evangélicas têm seus parlamentares no Poder Legislativo Federal (Estaduais e Municipais). Entre outros objetivos e metas, essa 
estratégia geopolítica tem a ver com o processo de conquista de concessões de rádios e canais de televisão que passam pelo Congresso Nacional, além do pragmatismo político para a conquista de cargos nos governos, especialmente no federal (BAPTISTA, 2009).

No tabuleiro de xadrez das geopolíticas das igrejas, algumas até pregando a intolerância religiosa, certos profissionais do mercado religioso se colocam na sociedade com discurso etnocêntrico e de verdade absoluta. Por exemplo, os fundadores das igrejas Universal - IURD (Edir Macedo) e da Igreja Internacional da Graça (R.R.Soares), entre outros, que pregam a intolerância em relação aos cultos afro-brasileiros (candomblé e umbanda), ao espiritismo (ou kardecismo) e ao catolicismo popular que valoriza o simbolismo das imagens (SILVA, 2007).

Contudo, como o que há de permanente é a mudança, caberia indagar: até que ponto os fiéis das igrejas mantêm fidelidade aos seus pastores ou líderes? Se, de um lado, os evangélicos crescem, de outro, cresce também a população sem religião. Aliás, o Censo Demográfico (IBGE, 2000) constatou que os estados brasileiros que possuíam os maiores percentuais de evangélicos, Rio de Janeiro (22\%), Espírito Santo (25\%) e Rondônia (27\%), também registraram os maiores percentuais de população sem religião: RJ (16\%), ES (10\%) e RO (13\%).

No contexto das geopolíticas das igrejas no Brasil, ou no complexo tabuleiro de xadrez das religiões, é notável a presença das igrejas no território brasileiro. Primeiramente, por influência do Vaticano no sentido da expansão do poder religioso católico, a partir do inicio da colonização, especialmente começando pelo nordeste brasileiro onde até hoje se concentram os maiores percentuais de população católica. Pode-se assim dizer que a geopolítica do Vaticano, ou da Igreja Católica, para a conquista do Brasil existe efetivamente, pelo menos, desde a chegada dos padres jesuítas no século XVI, contexto histórico da Reforma Protestante na Europa a partir de 1517. A geopolítica do Vaticano atuou no Brasil, por exemplo, contra o movimento de Teologia da Libertação nas décadas de 1970 e 1980

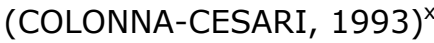

Nos últimos cinco séculos a geopolítica do Vaticano, através de seu serviço secreto, interferiu em todos os grandes e importantes fatos da história, desde a Contra-reforma até a queda do "comunismo" no Leste Europeu (FRATTINI, 2009) $)^{x i}$

Por outro lado, as igrejas evangélicas foram implantadas no território brasileiro a partir do século XIX, começando com as de origem do protestantismo clássico (luteranas, presbiterianas, metodistas, batistas, etc). Depois no século XX, a partir de 1910, com as igrejas pentecostais (Assembléia de Deus, Congregação Cristã no Brasil). Mais tarde, a partir da década de 1970, com as igrejas neopentecostais (Igreja Universal, Internacional da Graça, Renascer, Igreja Mundial, etc), processo que se expande no território brasileiro.

Além da conquista de mais população religiosa, mais dízimo, as geopolíticas das igrejas evangélicas, a partir do contexto histórico-político de redemocratização brasileira (final da década de 1970 e inicio de 1980) investiram na estratégia de eleição de parlamentares para o Congresso Nacional. Se no passado havia certo distanciamento dos evangélicos em relação à política partidária, a nova estratégia foi impulsionada com o lema: "Irmão vota em irmão" (PIERUCCI \& PRANDI, 1996). 
Essa nova estratégia adotada na geopolítica das igrejas contribui para o crescimento de deputados federais no Congresso Nacional brasileiro, como demonstra a tabela a seguir:

Deputados Evangélicos no Congresso Nacional

\begin{tabular}{c|c|c|c}
\hline 1982 & 1990 & 1998 & 2002 \\
\hline 12 & 23 & 51 & 60 \\
\hline
\end{tabular}

Fonte: Adaptado de BAPTISTA (2009)

Quanto à expansão dos templos de igrejas evangélicas no território brasileiro, pode-se deduzir que não ocorrem de modo aleatório. Contudo, a dedução se confirma a partir das nossas pesquisas de campo. Huntington (2004) e Berger \& Huntington (2004) defendem a expansão do pentecostalismo na América Latina e no mundo. Contata-se que existe uma inteligência geopolítica religiosa através do Serviço de Evangelização para a América Latina (SEPAL), segundo o pastor Rubens Muzio (MUZIO, 2004):

Com a presença de, pelo menos, uma igreja ao alcance de cada 1.000 habitantes, poderíamos dizer que o Evangelho do Reino está acessível a todos os brasileiros. As pesquisas do [Projeto] Brasil 2010 apontam para a presença de 100 a 140 mil igrejas evangélicas em todo o território nacional. Falta ainda a implantação intencional e estratégica de pelo menos 100 mil novas igrejas em todas as cidades, vilarejos, bairros e grupos étnicos ainda não alcançados. (...)

Qualquer negligência da geopolítica na vida da Igreja é trágica. (grifo nosso) ${ }^{\mathrm{xii}}$

A construção de templos religiosos se configura como uma estratégia na complexa geopolítica das igrejas evangélicas. O caso da Igreja Universal do Reino de Deus (IURD) se tornou evidente. Embora a IURD não seja a denominação com o maior número de seguidores evangélicos, essa igreja optou pela construção de templos como conquista do espaço urbano. Nota-se, porém, que a frequência aos templos da IURD diminuiu fato que se evidencia no cotidiano com igrejas quase vazias, bem como a perda de $25 \%$ de fiéis (IBGE- POF, 2003-2009).

Do ponto de vista da antropologia social, segundo a antropóloga Edlaine GOMES (2009), o circuito de conquista da cidade através da construção de suas catedrais expressa a maneira como a IURD representa a materialização da "permanência e consolidação do projeto da igreja, como monumento da cidade, como é o caso da concepção simbólica e arquitetônica de sua sede mundial" (GOMES,, 2009) ${ }^{\text {xiii }}$.

Aqui não se nega o simbolismo, porém, do ponto de vista epistemológico deste olhar geográfico, a construção de templos da IURD em lugares de grande circulação (ruas e avenidas de acessos principais em várias capitais brasileiras) se configura também como estratégia geopolítica de representação e domínio do território, na relação entre religião-população e poder como sugere Raffestin (RAFFESTIN, 1993).

Embora existam inúmeras religiões no Brasil, as geopolíticas, as rivalidades de poderes e influências no território brasileiro se explicitam com mais evidências entre a Igreja Católica e as Igrejas Evangélicas. Todavia, existem também disputas geopolíticas no interior do espaço evangélico, por exemplo, entre a Igreja Universal e a Igreja Mundial, fato que contribui para a perda de $25 \%$ de fiéis da IURD e, ao mesmo tempo, crescimento dos "evangélicos sem igrejas", segmento que aumento de $4 \%$ em 2003, para 14\% em 2009, segundo a 
Pesquisa por Orçamento Familiar - POF $(\mathrm{IBGE})^{\mathrm{xiv}}$.

A geopolítica das igrejas também se explicita nos meios de comunicação, especialmente através do rádio e da televisão, sem falar no ciberespaço, na internet. Em muitos programas evangélicos a intolerância faz parte do discurso de seus apresentadores, seja de modo implícito ou explicito. O poder religioso na mídia se configura como estratégia de conquista de novos fiéis. (FONSECA, 2003) ${ }^{x v}$.

\section{População sem religião ou anarquia religiosa no Brasil?}

Em que pesem as geopolíticas das igrejas, como "tudo que é sólido, desmancha no $a r^{\prime \prime}$, ou como o que há de permanente é a mudança, a realidade social das populações religiosas no Brasil revela um lento e fecundo processo de emancipação espiritual, de autonomia da fé, o que estamos denominando de anarquia religiosa.

Sabe-se que no senso comum a palavra "anarquia" relaciona-se com desordem ou bagunça. Mas buscando-se o sentido etimológico, segundo COSTA (1980) "a palavra anarchos, em grego, pode ser usada para definir desordem na falta de um governo, ou quando não existe a necessidade dele. Portanto, anarquia etimologicamente quer dizer sem governo, sem autoridade, sem superiores. Somente."

Mas o que vem a ser anarquia religiosa? É necessário esclarecer. A essência da anarquia religiosa fundamenta-se numa visão epistemo-ontológica de diálogo aberto entre a teoria da complexidade ou pensamento complexo (MORIN, 2005, 2007) e $o$ pensamento filosófico do geógrafo Kropotkin (2001), cujo ideal e filosofia da anarquia aponta para outra sociedade que se deseja mais justa, humana e fundamentada no "apoio mútuo" (KROPOTKIN, 2009). "Ana" em grego significa entre muitas outras coisas, "levantar de baixo para cima", e arkhé, princípio, comando, chefia.

Nesse sentido, o crescimento da população sem religião, especialmente a partir da década de 1980, uma tendência na sociedade brasileira, configura-se, a meu ver, como processo lento e fecundo de emancipação espiritual, na medida em que essa população desenvolve a autonomia da fé, processo gradual de desalienação do patrimônio espiritual.

Os dados da pesquisa, nas entrevistas, apontam para um movimento que vem de baixo, por iniciativa dos indivíduos, sem o governo das autoridades das igrejas. Isso ocorre por vários motivos: o descrédito em relação às autoridades das igrejas por conta de inúmeros escândalos; maior acesso à informação e ao conhecimento científico, mas também pelo entendimento das pessoas de que fora das igrejas existe espiritualidade.

A população sem religião não abre mão da fé, mas faz crítica e se distancia cada vez mais das igrejas. Ou seja, a anarquia religiosa se constitui como já dissemos, num processo fecundo de emancipação espiritual, de construção da autonomia da fé, do autogoverno do patrimônio espiritual (ou imaterial) dessa população.

Entre as populações religiosas que se declaram sem religião não se contabilizam as populações católicas e evangélicas não praticantes. Historicamente sabe-se que muitos católicos se autodenominam como "católico não praticante". Como sintetizou o sociólogo Flávio Pierucci, "é fácil ser católico", uma vez que $58 \%$ dos católicos não praticam sua religião (PIERUCCI, 2007) xvi $^{\text {(a) }}$

Embora ocorra 0 que alguns sociólogos denominam de "retorno do sagrado", ou pelo menos da conversão ao 
pentecostalismo e neopentecostalismo principalmente - processo esse que Peter Berger (2001) chama de "dessecularização" , é preciso considerar que o processo de secularização continua. O percentual da população sem religião no Brasil cresce coincidentemente nos estados onde crescem os evangélicos, como mostram os dados a seguir:

Estados brasileiros com maior percentual de Evangélicos e de População Sem religião - 1991/2000 (em \%)

\begin{tabular}{|c|c|c|c|c|}
\hline \multirow[b]{2}{*}{ Estados } & \multicolumn{2}{|c|}{ Evangélicos } & \multicolumn{2}{|c|}{ Sem Religião } \\
\hline & 1991 & 2000 & 1991 & 2000 \\
\hline Rondônia & 20,6 & 27,2 & 6,92 & 12,7 \\
\hline $\begin{array}{l}\text { Espírito } \\
\text { Santo }\end{array}$ & 17,2 & 24,96 & 6,03 & 9,6 \\
\hline $\begin{array}{ll}\text { Rio } & \text { de } \\
\text { Janeiro } & \\
\end{array}$ & 12,1 & 21,98 & 13,74 & 15,76 \\
\hline Goiás & 11,3 & 19,96 & 5,16 & 7,9 \\
\hline $\begin{array}{l}\text { Rio Grande } \\
\text { do Sul }\end{array}$ & 10,8 & 14,30 & 2,92 & 4,7 \\
\hline $\begin{array}{l}\text { Média } \\
\text { Nacional }\end{array}$ & 8,56 & 15,41 & 4,73 & 7,3 \\
\hline
\end{tabular}

Fonte: IBGE - Censo Demográfico

É importante destacar que a contribuição do protestantismo para o processo de crescimento do contingente populacional sem religião, tem a ver com o que os intelectuais protestantes chamam de "crise do evangelismo" verificada desde a década de 1990 (ROMEIRO, 1995). E essa "crise do evangelismo" pode ser constatada em estudos de intelectuais protestantes como, por exemplo, nas obras: "Igreja? tô fora!" (AGRESTE, 2007); "Feridos em nome de Deus" (CESAR, 2009) e "O que estão fazendo com a Igreja" (NICODEMUS, 2010).

Contudo, a população sem religião se constitui como fenômeno generalizado e disperso em todo território nacional, embora nos grandes centros urbanos, nas capitais brasileiras e também em importantes capitais interioranas, esse fenômeno seja mais acentuado. Além disso, as populações sem religião estão dispersas em todas as classes sociais e em todas as faixas etárias.

Em grande medida a população sem religião se concentra nas áreas metropolitanas, nos grandes centros urbanos, onde se encontra a maior densidade populacional. Mas esse fenômeno verifica-se também em importantes capitais interioranas como, por exemplo, Cuiabá (MT) e Campo Grande (MS) com mais de $11 \%$ de população sem religião. (Veja Cartograma 01) ${ }^{\mathrm{xvii}}$.

$\mathrm{Na}$ verdade, a anarquia religiosa, o fenômeno da população sem religião se dispersa desigualmente em todo o território brasileiro. Na região norte do país, no estado de Rondônia, por exemplo, o percentual de população sem religião atinge quase $13 \%$, situação semelhante à região leste do Acre e sudoeste do Pará (IBGE, 2000).

Já na região sudeste, o estado do Rio de Janeiro se destaca como primeiro com o maior percentual de população sem religião com quase 16\%. Na região metropolitana, porém, esse percentual ultrapassa a cifra de $24 \%$ de população sem religião. Destacamos, por exemplo, na região serrana as cidades Teresópolis (18\%), Guapimirim (20\%) e outras cidades fluminenses como Itaboraí (22\%) e Tanguá (27\%) com altos percentuais de população sem religião (IBGE, 2000). 


\section{Cartograma 01 População sem religião no Brasil - 2000}

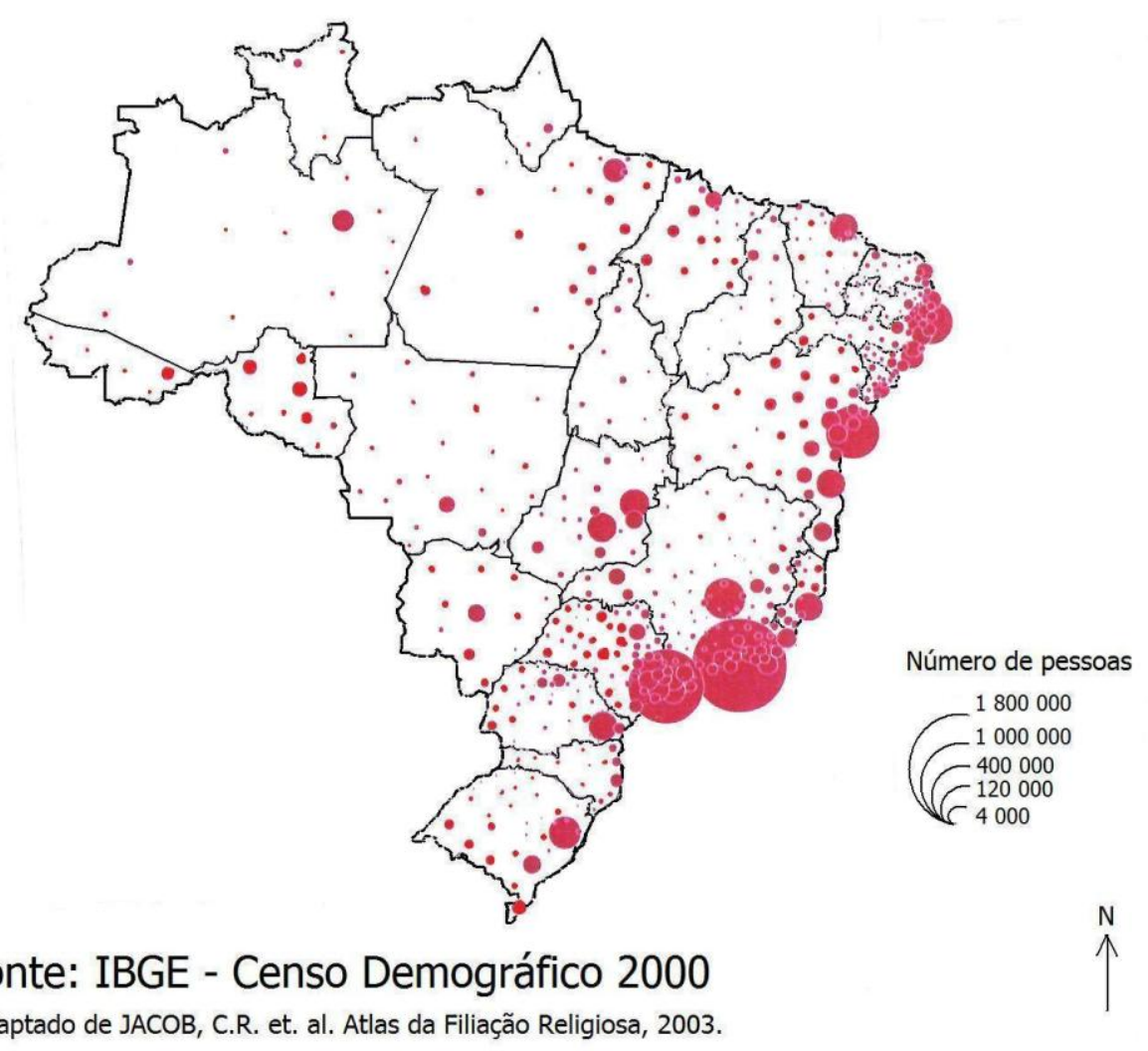

\section{Considerações finais}

Este artigo procurou sintetizar a seguinte tese: existem geopolíticas das igrejas católica e evangélicas e, ao mesmo tempo, a ausência de governo das igrejas sobre o crescimento da população sem religião, isto é, anarquia religiosa no Brasil.

A geopolítica do Vaticano, desde a época da Contra-reforma no século XVI, e mais tarde as geopolíticas das igrejas protestantes a partir do século XIX, contribuíram para a expansão do cristianismo no território brasileiro. Contudo, as críticas às geopolíticas das igrejas não vem de fora, mas sim de dentro das próprias igrejas tanto católica como evangélicas. E essas críticas são históricas.

No cenário da ordem mundial de Guerra Fria (EUA versus URSS), a geopolítica do Vaticano fez aliança com a "direita cristã" norte-americana. De um lado, o Vaticano combatendo o movimento católico de contestação de influência marxista orientado pela Teologia da Libertação e, ao mesmo tempo, apoiando o movimento de Renovação Carismática Católica no Brasil; de outro lado, o governo norte-americano combatendo a influência ou pretensa expansão do "comunismo" na América Latina. (COLONNACESARI, 1993). 
No caso do protestantismo no Brasil (MENDONÇA, 2005) existe rica diversidade, porém, em mudança. A geopolítica das igrejas protestantes contribui para o crescimento da população evangélica no Brasil. Essa expansão é defendida por pensadores norte-americanos como, por exemplo, Samuel Huntington $(1997,2004)$ e Peter Berger (2004).

Contudo, numa aparente desordem, o crescimento da população evangélica vem sendo acompanhado pela "crise do evangelismo" (ROMEIRO, 1995), pela critica ao modelo atual da igreja protestante e, ao mesmo tempo, perda de fiéis (AGRESTE, 2007) e por inúmeros casos de religiosos "feridos em nome de Deus" por conta do "abuso espiritual" praticado por pastores evangélicos (CESAR, 2009). Isso sem falar na descrença de certos pastores e teólogos, cuja crise de todo esse processo talvez pudesse ser sintetizada no subtítulo da obra de um teólogo protestante: "ascensão e queda do movimento evangélico brasileiro" (NICODEMUS, 2010).

Outras religiões populares brasileiras e suas formas de organização, por exemplo, o espiritismo cujo movimento é socialmente anárquico (JACINTHO, 1984), bem como suas filosofias ou ideias participam das territorialidades das populações religiosas e contribuem, num processo dialético e sem governo para a metamorfose das religiosidades. Isto é, transformação e construção de outra ordem espiritual fundada na autonomia da fé, cada pessoa governando seu patrimônio espiritual, porém, com apoio mútuo.

Esse processo, a meu ver, favorece ao que entendemos como diálogo transreligioso, isto é, a tolerância espiritual aberta e sem distinção de sentidos de crenças e/ou visões de mundo. Esse processo transcende a esfera das religiões e de seus dogmas, uma vez que está na esfera da autonomia das pessoas, portanto, se configura como um processo dialético sem governo das igrejas.

Vale ressaltar, porém, que além da população sem religião, talvez haja parcela da população religiosa que possui mentalidades vanguardistas $e$, de certo modo, anárquicas, que contesta o poder religioso institucionalizado.

No Protestantismo, inclusive, existe certa visão de autonomia da fé e/ou governo de si mesmo a partir do ascetismo, como sugere a geógrafa Amélia Damiani (1991). Em suas palavras: "Cada um de nós leva seu Deus junto a si; o ascetismo se dá sem autoridade formal. Cada um de nós se encarrega de reprimir seus próprios desejos e suas necessidades. Ele pode se constituir num processo de auto-repressão." (DAMIANI, 1991, p. 88).

Este artigo é uma tentativa de explicar um aspecto, no espaço e no tempo, da realidade complexa, ou um esforço reflexivo em dar sentido epistemo-ontológico ao que aparentemente seria caótico. Mas terá que passar pelo purgatório da crítica.

Talvez, para além da aparente desordem das geopolíticas das igrejas intolerantes, que pretendem a hegemonia religiosa com a máxima "haverá um só rebanho e um só pastor", o processo de anarquia religiosa no Brasil - algo que contribui para o aperfeiçoamento e fortalecimento da cidadania no Estado Democrático de Direito - sinalize para uma nova ordem espiritual.

No cenário de relações internacionais de governança sem governo no século XXI (ROSENAU, 2000), talvez a anarquia religiosa no Brasil contribua para uma geoética do apoio mútuo em prol da sustentabilidade sócio-ambiente-espiritual do maior e mesmo "templo" da humanidade: a Terra. 
Como saber? Somente a dinâmica do tempo na geografia do cotidiano (e a história do pensamento geográfico) poderá, no futuro, revelar...

\section{REFERÊNCIAS BIBLIOGRÁFICAS}

AGRESTE, Ricardo. Igreja? tô fora! Santa Barbara d'Oeste-SP: Socep, 2007.

APPLE, Michael W. Educando à Direita mercados, padrões, Deus e desigualdade. São Paulo: Cortez, 2002.

BAPTISTA, Saulo. Pentecostais e Neopentecostais na Política Brasileira. São Paulo: AnnaBlume, 2009.

BERGER, Peter. Dessecularização do mundo: uma visão global. Rio de Janeiro: Religião e Sociedade, vol.21, nº1, 2001.

BERGER, P. \& HUNTINGTON, S. (org.) Muitas Globalizações - diversidade cultural no mundo contemporâneo. Rio de Janeiro: Record, 2004.

CASTORIADIS, Cornelius. A Instituição Imaginária da Sociedade. 3a. ed. São Paulo: Paz e Terra, 1993

CARLOS, Ana F. A. "Crise e superação no âmbito da Geografia Crítica: construindo a Metageografia". São Paulo: GEOUSP - Espaço e Tempo, n.30, 2011, pp. 14-28.

COLONNA-CESARI, C. Urbi Et Orbi - $A$ Geopolítica do Vaticano. Lisboa-Portugal: Caminho, 1993.

COSTA, Caio Tulio. O Que é Anarquismo. São Paulo: Brasiliense, 1985.

CESAR, Marília C. Feridos em nome de Deus. São Paulo: Mundo Cristão, 2009.

DAMIANI, Amélia. População e Geografia. São Paulo: Contexto, 1991.

ELIADE, Mircea. O Sagrado e o Profano. São Paulo: Martin Fontes, 2001.
FOUCAULT, Michel. Microfísica do Poder. Rio de Janeiro: Graal, 1979.

FRATTINI, Eric. A Santa Aliança - cinco séculos de espionagem no Vaticano. São Paulo: Boitempo, 2009.

FREUD, Sigmund. O Futuro de uma ilusão. Rio de Janeiro: Imago, 1997.

GIL FILHO, Sylvio F. Por uma Geografia do Sagrado. Revista Ra'e Ga - O espaço geográfico em análise. v. 05, p.67 - 78, Curitiba: UFPR, 2001.

GOMES, Paulo C. C. "Que espaço poder haver para uma geografia cultural? Elementos para uma reflexão sobre a relação entre o cultural e o geográfico." IN: LEMOS, Amália I. G. \&

GALVANI, Emerson (Org.). Geografia, tradições e perspectivas. São Paulo: Departamento de Geografia- USP, Expressão Popular, V. 2, 2009.

HUNTINGTON, Samuel P. O Choque de Civilizações. Rio de Janeiro: Objetiva, 1997. Hispânicos são atrasados, diz Huntington. São Paulo: Entrevista, Folha de São Paulo, 27 de junho de 2004.

JACINTHO, Roque. O que é Espiritismo. São Paulo: Brasiliense, 1984.

KROPOTKIN, Piotr. A Anarquia - sua filosofia, seu ideal. Imaginário, São Paulo: 2001.

La seleccion natural Y El

Apoyo Mutuo. Madrid: C.S.I.C., 2009. 
LACOSTE, Yves (org.) A Geopolítica do Inglês. São Paulo: Parábola, 2005.

A Geografia, isso serve, em primeiro lugar, para fazer a guerra. Campinas-SP: Papirus, 1989.

MAFRA, Clara \& ALMEIDA, Ronaldo (org.). Religiões e Cidades - Rio de Janeiro e São Paulo. São Paulo: Terceiro Nome/Fapesp, 2009.

MARIANO, Ricardo. Neopentecostais: sociologia do novo pentecostalismo no Brasil. São Paulo: Loyola, 1999.

MAQUIAVEL, N. O Príncipe. Porto Alegre: L\&PM, 1998.

MARX, Karl. A Questão Judaica. Rio de Janeiro: Laemmert, 1969.

MENDONÇA, Antonio G. "O protestantismo no Brasil e suas encruzilhadas". São Paulo: Revista USP, n. 67, 2005, pp. 48-67.

MUZIO, Rubens R. (org.) A Revolução Silenciosa - transformando cidades pela implantação de igrejas saudáveis. São Paulo: Sepal, 2004.

MORIN, Edgar. Os sete saberes necessários à educação do Futuro. $10^{a}$ ed. São Paulo: Cortez/Unesco, 2005.

Introdução ao Pensamento

Complexo. Porto Alegre: Sulina, 2007.

NICODEMUS, Augustus. O que estão fazendo com a Igreja - ascensão e queda do movimento evangélico brasileiro. São Paulo: Mundo Cristão, 2010.

NOVAES, Regina. Os jovens "sem religião". IN: Dossiê Religiões no Brasil. Estudos Avançados, 52, USP, 2004, p. 321-330.
PIERUCCI, Flávio \& PRANDI, Reginaldo. $A$ realidade social das religiões no Brasil. São Paulo: Hucitec, 1996.

RECLUS, Élisée. A Evolução, a Revolução e o Ideal Anarquista. São Paulo: Imaginário, 2002.

RIBEIRO, Jorge C. Religiosidade Jovem. São Paulo: Loyola, 2009.

ROMEIRO, Paulo. Evangélicos em crise. São Paulo: Mundo Cristão, 1995.

ROSENAU, James et al (Orgs). Governança sem governo - ordem e transformação na política mundial. Brasília: UnB; São Paulo: Imprensa Oficial do Estado: 2000.

ROSENDAHL, Zeny. Porto das Caixas: Espaço Sagrado da Baixada Fluminense. São Paulo: Tese doutorado, USP, 1994.

Espaço e Religião: uma abordagem geográfica. Rio de Janeiro: EdUERJ, 1996.

SILVA, Vagner G (org.). Intolerância Religiosa - Impactos do neopentecostalismo no campo religioso afro-brasileiro. São Paulo: EDUSP, 2007.

SOJA, Edward W. Geografias Pós-modernas. Rio de Janeiro: Jorge Zahar, 1993.

VESENTINI, J. William. Novas Geopolíticas. São Paulo: Contexto, 2000.

A atualidade de Kropotkin, geógrafo e anarquista. IN: VESENTINI, J.W. Ensaios de Geografia Crítica. São Paulo: Ed. Plêiade, 2009.

Weber, Max. A Ética Protestante e o espírito do capitalismo. São Paulo: Martin Claret, 2004.

Sociologia da Religião. IN: Economia e Sociedade. Brasília: UnB, 1984. 


\section{NOTAS}

i A primeira versão deste artigo, submetido à Revista GEOUSP, foi intitulada "Geopolítica, Igrejas e Anarquia Religiosa no Brasil". Agradeço aos Avaliadores (Ad hoc) pelas críticas e sugestões que contribuíram para o aperfeiçoamento deste texto, bem como ao CNPq pela Bolsa de Estudo concedida durante uma etapa da pesquisa, entre 2007 e 2008.

A tese foi disponibilizada na Biblioteca Digital da USP. A primeira versão deste artigo havia sido escrita há dez meses antes da finalização da tese. Aqui cabe registrar a valiosa contribuição dos Avaliadores (Revista GEOUSP), através do parecer sobre a primeira versão do artigo. Ressalto que foram mais de cinquenta comentários críticos, sobre os quais, com paciência, procurei me debruçar num processo de reflexão e reelaboração do presente texto.

ii A respeito do ateísmo, numa visão que defende o diálogo e a tolerância em relação às religiões, ver a obra do filósofo ateu, Alain de BOTTON. Religião para Ateus. Rio de Janeiro: Intrínseca, 2011. BOTTON se distancia dos ateus radicais que e preocupam em criticar as religiões. O Autor, inclusive, sugere que os ateus têm algo a aprender com as religiões.

iii A respeito da cidadania sob a poliarquia, Rosenau entende que a crise de autoridade nos pós-Guerra Fria ou ordem mundial de governança sem governo influencia na esfera dos cidadãos e estes, como atores, influenciam na política interna dos Estados que, por sua vez, redefinem seu papel nas relações internacionais. ROSENAU, James. (Org). Governança sem governo - ordem e transformação na política mundial. Brasília: UnB; São Paulo: Imprensa Oficial do Estado, 2000, pp. 363-392.

iv O neologismo "geoética" tem a ver com uma visão epistemológica partindo da Geografia fundamentada na teoria da complexidade (MORIN), entre outras teorias.

$\checkmark$ Além da vasta bibliografia analisada, das estatísticas do IBGE, das observações de campo e coleta de material em seis municípios da Região Metropolitana de São Paulo, em Crato e Juazeiro do Norte (CE) e em Londrina-PR, foram realizadas 83 entrevistas semi-estruturas entre maio e agosto de 2010. Contudo, desde a década de 1990 temos pesquisado a dimensão geográfica das religiões no Brasil. Portanto, o período histórico da pesquisa se concentrou entre 1990 e 2010.

vi RECLUS, Élisée. A Evolução, a Revolução e o Ideal Anarquista. São Paulo: Imaginário, 2002, pp. 11.

vii "A atualidade de Kropotkin, geógrafo e anarquista". IN: VESENTINI, J.W. Ensaios de Geografia Crítica. São Paulo: Editora Plêiade, 2009, pp.171-193

viii KROPOTKIN, Piotr. A Anarquia, sua filosofia, seu ideal. São Paulo: Imaginário, 2001, pp.88-93. ix KROPOTKIN, Piotr. La seleccion natural y el Apoyo mutuo. Madrid: CSIC, 2009.

× Em 2010, no segundo turno das eleições para presidente do Brasil - Dilma Rousseff (PT) X José Serra (PSDB) -, o Papa Bento XVI se pronunciou recomendando aos bispos brasileiros que orientassem politicamente os fiéis católicos a não votar em candidato que defende a descriminalização do aborto (Folha de São Paulo, $28 / 10 / 2010$ ). No entanto, no nordeste brasileiro onde se concentra o maior contingente proporcional de católicos, Dilma Rousseff foi eleita com mais de $70 \%$ dos votos válidos. (TSE/Folha de São Paulo, 01/11/2010).

xi FRATTINI, Eric. A Santa Aliança - cinco séculos de espionagem no Vaticano. São Paulo: Boitempo, 2009. Nesta obra, fruto de vasta pesquisa documental com base em diversos historiadores e arquivos históricos europeus, o autor explicita com detalhes as ações do serviço secreto do Vaticano, a Santa Aliança, fundada em 1566, embora até hoje negada pelo Vaticano.

xii MUZIO, Rubens R. A Revolução Silenciosatransformando cidades pela implantação de igrejas saudáveis. São Paulo, SEPAL, 2004, pp. 26-28. Atualmente a sigla SEPAL mudou para "Servindo aos Pastores e Líderes"

xiii GOMES, Edlaine C. Ser única e Universal: materializando a autenticidade na cidade do Rio de Janeiro. IN: MAFRA, C. \& ALMEIDA, R. (org). Religiões e Cidades - Rio de Janeiro e São Paulo. São Paulo: Terceiro Nome/Fapesp, 2009, p.111132.

xiv Pesquisa por Orçamento Familiar (POF), divulgada pela Folha de São Paulo, Caderno Poder: 15 de agosto 2011.

$x v$ FONSECA, Alexandre B. "Igreja Universal: um império midiático". IN: ORO, Ari Pedro et al. (org.). Igreja Universal: os novos conquistadores da fé. São Paulo: Paulina, 2003.

xvi PIERUCCI, Flávio. É fácil ser católico. São Paulo: Folha de São Paulo, 06/05/2007. Em 1991, a Revista Veja (25/12/1991) publicou matéria de capa "A decadência do catolicismo no Brasil" com dados de pesquisa do Instituto Gallup revelando que apenas 34\% dos católicos eram praticantes da religião. $\mathrm{Na}$ mesma reportagem, divulgou entrevistas com o vice-reitor da PUC-MG, padre Alberto Antoniazzi, da Diocese de Belo Horizonte e com o bispo Dom Boaventura Kloppenburg, da Diocese de Novo Hamburgo (RS), ambos estarrecidos por constatarem que somente $29 \%$ e $11 \%$ dos católicos eram praticantes em suas respectivas Dioceses, segundo pesquisa realizada por eles.

xvii Ressalto que, na tese, foram inseridos vinte cartogramas representando as populações religiosas no Brasil. Mais detalhes ver: JACOB, C. R et al. Atlas da Filiação Religiosa no Brasil. São Paulo: Loyola, PUC-Rio, 2003. 